\title{
Perencanaan Struktur Ruang Lansekap Kawasan Pesisir Berbasis Mitigasi Bencana (Studi Kasus : Desa Alue Naga, Kecamatan Syiah Kuala, Banda Aceh)
}

\author{
Delfi Astari ${ }^{a^{*}}$, Elysa Wulandari ${ }^{a}$, Cut Nursaniah ${ }^{a}$ \\ a Jurusan Arsitektur dan Perencanaan, Fakultas Teknik, Universitas Syiah Kuala, Indonesia \\ *E-mail korespondensi: delfiastari97@gmail.com
}

\begin{abstract}
Abstrak: Letak geografisnya menjadikan Alue Naga sebagai salah satu kawasan pesisir Banda Aceh yang rentan terhadap bahaya tsunami. Penelitian ini bertujuan untuk mengidentifikasi permasalahan kerentanan yang ada di dalam kawasan sehingga dapat diketahui penerapan mitigasi yang sesuai. Metode penelitian yang digunakan adalah metode mix method, data yang telah diperoleh disederhanakan kembali secara kualitatif deskriptif. Teori permukiman Doxiodis digunakan sebagai landasan penelitian untuk menilai 5 aspek penting di dalam kawasan. Tingkat kerentanan Alue Naga terhadap bahaya tsunami sangat tinggi dengan fisik hunian, tatanan ruang serta unsur buatan yang penggunaannya belum maksimal sebagai mitigasi. Pendidikan serta kepedulian masyarat akan mitigasi dan evakuasi juga masih sangat kurang. Pola penataan ruang permukiman yang sejajar dengan garis pantai, penambahan unsur buatan serta penerapan rumah panggung sebagai respon adaptasi akomodatif dianggap sebagai langkah penting untuk dilakukan. Potensi kawasan yang menjadi habitat mangrove dikembangkan kembali sebagai buffer mitigasi, sarana rekreasi dan pundi ekonomi penduduk lokal. Peninggian elevasi dilakukan pada area tertentu seperti titik evakuasi yakni dengan penimbunan untuk mensiasati energi gelombang serta kondisi tanah alluvial yang peka erosi.
\end{abstract}

Kata kunci: Kawasan pesisir, Kerentanan, Mitigasi tsunami, Struktur ruang, Banda Aceh.

\begin{abstract}
Geographical location makes Alue Naga as one of Banda Aceh coastal areas that vulnerable to tsunami. This study aims to indetify the vulnerability problems in the area so the appropriate mitigation application can be identified. Research method used is mix method, the data that has been obtained simplified again with descriptive qualitative. Doxiadis theory of human settlement is used as research basis to asses 5 important aspect in the area. Alue Naga vulnerability level to tsunami hazard is high, meanwhile physical housing, spatial arrangement and artificial elements whose use has not been maximized as mitigation. Education and public awareness of mitigation and evacuation are still lacking. Spatial planning parallel to the coastline, the addition of artificial element and application house of stilts as an accommodative adaptation response are considered important steps to take. Mangrove habitats are redeveloped as mitigation buffer, recreational facilities and economic coffers for local population. Increasing the elevation in certain areas such as evacuation points by stockpiling to anticipate wave energy and erosion-sensitive alluvial soil condition.
\end{abstract}

Keywords: Coastal, Vulnerability, Tsunami mitigation, Spatial structure, Banda Aceh.

How to cite (APA 6th Style):

Astari, Delfi; Wulandari, Elysa; Nursaniah, Cut. (2021). Perencanaan Struktur Ruang Lansekap Kawasan Pesisir Berbasis Mitigasi Bencana (Studi Kasus : Desa Alue Naga, Kecamatan Syiah Kula, Banda Aceh), 2 (2), 19-28. doi: 10.26418/uniplan.v2i2.49111

\section{PENDAHULUAN}

Kawasan pesisir didefinisikan sebagai kawasan yang terletak antara daratan dan lautan (Asyiawati \& Akliyah, 2011), yang kedinamikaannya saling memberi pengaruh serta memiliki ciri yang dinamis dengan perubahan biologis, kimiawi dan geologis yang sangat cepat sehingga kawasan pesisir memiliki potensi sumber kehidupan yang tinggi sekaligus rentan terhadap bahaya alam dari arah laut (gelombang pasang, tsunami dan badai) serta dari arah darat (banjir kiriman). Bencana tsunami di Aceh tahun 2004 telah merusak, menghancurkan bahkan mengeliminasi permukiman disekitarnya (Wulandari et al., 2021).

Pasca tsunami, pantai Alue Naga mengalami perubahan morfologi pada garis pantai akibat abrasi. Perubahan yang nyata terlihat di Dusun Kutaran. Kondisi angin yang kencang membutuhkan perlindungan 
vegetasi untuk memperlambat aliran udara ke permukiman dan melindungi pantai dari abrasi (Nursaniah et al., 2021).

Pembangunan pasca tsunami meliputi relokasi perumahan ke daerah aman bencana dan ada juga yang kembali dibangun di tempat semula (E Wulandari. et al., 2020). Berdasarkan UU No. 4 Tahun 2004 pembangunan di daerah rawan bencana harus memperhatikan pendekatan mitigasi bencana, baik melalui pembangunan fisik maupun non-fisik (BNPB, 2020).

Bentuk hunian berkonstruksi panggung dianggap ideal untuk kawasan Alue Naga dan pesisir Utara Banda Aceh, guna merespon kelembaban dan gelombang pasang. Namun harus memiliki proteksi lingkungan permukiman berbentuk soft protection dan hard protection yang diupayakan oleh pemerintah dibantu pemberdayaan masyarakat setempat (Nursaniah et al., 2019).

Letak geografisnya membuat mayoritas masyarakatnya berprofesi sebagai nelayan, karenanya lingkungan perumahan juga berkembang sebagai perkampungan nelayan tradisional dengan tingkat kesejahteraan relatif rendah. Terdapat korelasi hubungan antar kualitas manusia terhadap kemampuan beradaptasi (Direja \& Wulan, 2018). Berdasarkan hal tersebut diatas maka tujuan dari tulisan ini difokuskan untuk mengkaji tingkat kerentanan bencana tsunami kawasan pesisir Alue Naga saat ini dan mengusulkan konsep struktur ruang berbasis mitigasi bencana yang sesuai dengan kondisi kawasan.

\section{DATA AND METODE}

Lokasi penelitian berada di kawasan Alue Naga bagian timur yang terdiri dari 2 dusun (Kutaran dan Po diamat) dengan dasar pertimbangan pemilihan lokasi karena kawasan berada di pinggiran Utara-Timur kota Banda Aceh yang masih berkarakter rural dengan lingkungan alam sekitarnya berupa rawa dan tambak yang menyebabkan area semakin rentan.

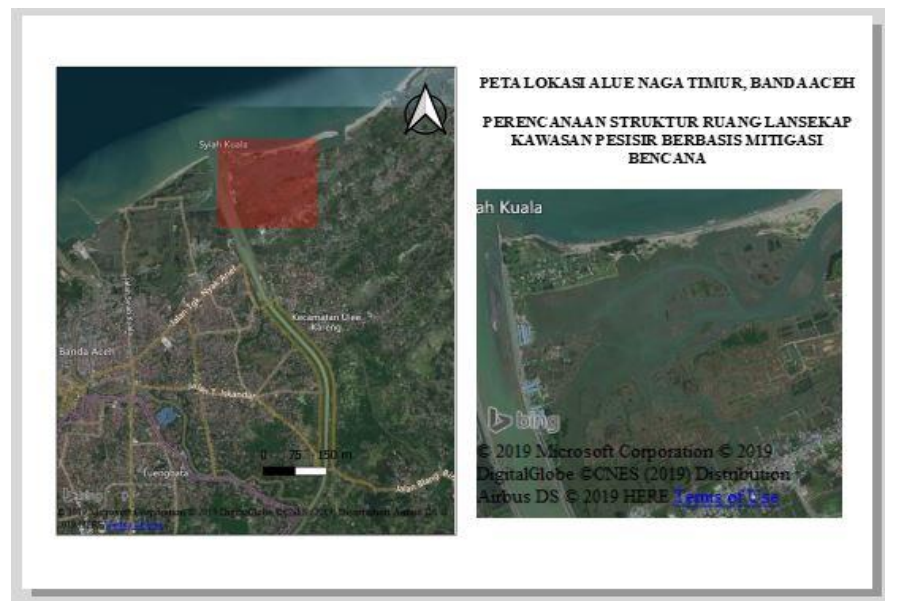

Gambar 1. Lokasi penelitian, Alue Naga Timur (QGIS, 2021)

Batasan materi disesuaikan dengan kajian pustaka yang berkaitan dengan tema penelitian. Teori Doxiadis (Fairuzahira et al., 2020) digunakan sebagai dasar analisis menilai 5 elemen permukiman untuk mengetahui lingkup permasalahan didalam kawasan.

Tabel 1. Variabel penelitian teori Doxiadis (Analisis, 2021)

\begin{tabular}{|l|l|l|l|l|}
\hline \multicolumn{1}{|c|}{ Variabel } & Aspek yang ditinjau & \multicolumn{1}{|c|}{ Karakteristik } & \multicolumn{1}{|c|}{ Maksud data } & \multicolumn{1}{|c|}{ Menilai } \\
\hline Alam/Nature & $\begin{array}{l}\text { Geografi, topografi, } \\
\text { geologi, karakteristik } \\
\text { tanah, vegetasi. }\end{array}$ & Kesesuaian & $\begin{array}{l}\text { Kemiringan, } \\
\text { ketinggian, jarak dari } \\
\text { pantai dan sugai, } \\
\text { tataguna lahan. }\end{array}$ & kerentanan \\
\hline Man/Manusia & Demografi & Populasi & $\begin{array}{l}\text { Aktivitas dalam } \\
\text { ruang }\end{array}$ & $\begin{array}{l}\text { Zonasi (mitigasi, } \\
\text { evakuasi) }\end{array}$ \\
\hline Social/Masyarakat & Demografi & Pendidikan & Mitigasi, evakuasi & Pemahaman \\
\hline
\end{tabular}




\begin{tabular}{|l|l|l|l|l|}
\hline & & kebencanaan & masyarakat \\
\hline Shell/Permukiman & $\begin{array}{l}\text { Rumah, perumahan, } \\
\text { bangunan umum, } \\
\text { unsur buatan }\end{array}$ & Kesesuaian & $\begin{array}{l}\text { Fisik, tata letak, } \\
\text { keefektivan }\end{array}$ & $\begin{array}{l}\text { Tatanan struktur } \\
\text { ruang }\end{array}$ \\
\hline Network/Jaringan & Eksisting & Kesesuaian & $\begin{array}{l}\text { Keterhubungan dan } \\
\text { kelayakan akses }\end{array}$ & Jalur evakuasi \\
\hline
\end{tabular}

Metode penelitian yang digunakan adalah metode mix methods yakni dengan menggunakan metode kualitatif dan kuantitatif secara bersamaan. Populasi dalam penelitian adalah penduduk Desa Alue Naga yang berada di 2 dusun, Kutaran ( $263 \mathrm{KK}$ ) dan Po diamat (48 KK) dengan total pupulasi $(\mathrm{N})=311 \mathrm{KK}$. Jumlah sampel di ambil berdasarkan rumus Slovin dengan nilai presisi 0,15, maka jumlah sampel yang digunakan adalah $\mathrm{n}=\mathrm{N} / \mathrm{N}(\mathrm{d})^{2}+1=311 / 311(0,15)^{2}+1=38,88$ dibulatkan menjadi 39 orang.

Teknik pengambilan sampel yang digunakan adalah Simple Random Sampling, pemilihan teknik ini dikarenakan adanya keterbatasan tenaga, waktu dan biaya sehingga sampel akan dipilih secara random dari rumah ke rumah. Koefisien korelasi ditentukan dengan rumus; $\{\mathbf{d f}=\mathbf{n}-\mathbf{2}\}$ sehingga $\mathrm{df}=\mathbf{3 9}-\mathbf{2}=37$ dengan taraf siknifikan $10 \%(0,1)$ maka koefisien $r$ tabel yang digunakan 0,2673 sehingga hasil data yang di dapatkan adalah valid.

Pengumpulan data dengan kuesioner hanya digunakan untuk menilai variable Man dan Social dengan dasar pembuatan kuisioner berdasarkan buku Latihan Kesiapsiagaan Bencana. Point utama yang dinilai adalah tindakan sebelum bencana (mitigasi) dan tindakan saat terjadi bencana (evakuasi). Adapun pengumpulan data secara observasi dilakukan langsung di lapangan untuk mengetahui kondisi real objek penelitian. Hasil data yang telah di dapat akan disederhanakan kembali secara kualitatif deskriptif dengan melihat logika dan penggunaan ruang kawasan.

\section{HASIL DAN PEMBAHASAN}

\subsection{Karakteristik Kerentanan Kawasan Alue Naga}

\section{a. Variabel Alam (Nature)}

Geografi pantai landai sebagai daerah delta dari aliran banjir kanal Krueng Lamnyong, memiliki kontur datar dengan elevasi rata-rata 3,18 (dpl) dan persentase kemiringan lahan dibawah $2 \%$ sehingga sangat tinggi terhadap ancaman tsunami. Jenis tanah berupa jenis alluvial yang tersusun dari kerikil, pasir dan lempung. Jenis tanah seperti ini sangat peka terhadap erosi dikarenakan berstruktur pasir dari hasil sedimentasi.

Morfologi Alue Naga timur dipengaruhi oleh aliran sungai dan arus air laut yang membentuk rawa/wetland. Luasan wetland semakin menyempit tiap tahunnya akibat sedimentasi, sementara peningkatan aspek sosial ekonomi mendorong semakin luasnya tambak yang mempersempit luasan hutan mangrove. Penggunaan lahan masih sangat didominasi oleh kawasan tidak terbangun namun telah berkembang perumahan yang tumbuh secara tersebar sekitar $6,29 \%$. Berikut data tata guna lahan;

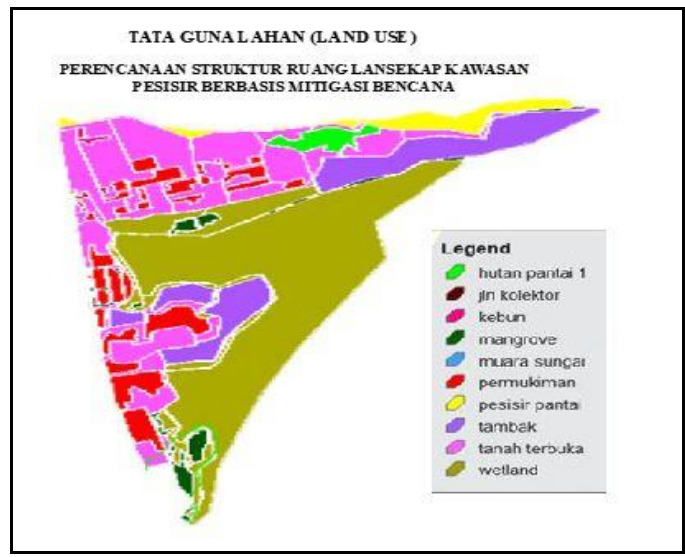


Gambar 2. Tata guna lahan/land use (QGIS, 2021)

Tabel 2. Land cover (QGIS, 2021)

\begin{tabular}{|l|l|l|l|}
\hline No. & \multicolumn{1}{|c|}{$\begin{array}{c}\text { Penggunaan } \\
\text { Lahan }\end{array}$} & Hektare & persentase \\
\hline 1. & Hutan pantai & 1,78 & 1,04 \\
\hline 2. & Jalan kolektor & 0,96 & 0,56 \\
\hline 3. & Kebun & 0,27 & 0,15 \\
\hline 4. & Mangrove & 2,51 & 1,47 \\
\hline 5. & Muara sungai & 51,9 & 30,43 \\
\hline 6. & Permukiman & 10,73 & 6,29 \\
\hline 7. & Pesisir pantai & 4,87 & 2,85 \\
\hline 8. & Tambak & 13,33 & 7,81 \\
\hline 9. & Wetland & 38,1 & 22,34 \\
\hline 10. & Tanah terbuka & 46,12 & 27,04 \\
\hline & Total & $\mathbf{1 7 0 , 5}$ & $\mathbf{1 0 0}$ \\
\hline
\end{tabular}

Hasil analisis variabel alam (nature) menunjukkan bahwa kawasan Alue Naga timur memiliki tingkat kerentanan yang sangat tinggi terhadap bahaya tsunami yang penjelasannya disajikan dalam tabel berikut;

Tabel 3. Hasil anlisis tingkat kerentanan kawasan terhadap bahaya tsunami (Analisis, 2021)

\begin{tabular}{|l|l|l|l|l|}
\hline No. & Kriteria & Parameter & Score & $\begin{array}{l}\text { Tingkat } \\
\text { kerentanan }\end{array}$ \\
\hline 1. & Elevasi & $3,18 \mathrm{~m}$ & 5 & $\begin{array}{l}\text { Sangat } \\
\text { tinggi }\end{array}$ \\
\hline 2. & $\begin{array}{l}\text { Tata guna } \\
\text { lahan }\end{array}$ & $\begin{array}{l}\text { Tambak } \\
\text { dan kebun }\end{array}$ & 4 & Tinggi \\
\hline 3. & Kemiringan & $1,4 \%$ & 4 & Tinggi \\
\hline 4. & $\begin{array}{l}\text { Jarak dari } \\
\text { pantai }\end{array}$ & $\begin{array}{l}206 \mathrm{~m}- \\
1235 \mathrm{~m}\end{array}$ & 5 & $\begin{array}{l}\text { Sangat } \\
\text { tinggi }\end{array}$ \\
\hline 5. & $\begin{array}{l}\text { Jarak dari } \\
\text { sungai }\end{array}$ & $<100$ & 5 & $\begin{array}{l}\text { Sangat } \\
\text { tinggi }\end{array}$ \\
\hline
\end{tabular}

\subsection{Kesesuaian Permukiman (Shell) dan Jaringan (Netwok) terhadap Mitigasi Tsunami}

a. Variabel permukiman (Shell)

Fisik hunian rumah bantuan di dalam kawasan kebanyakan adalah rumah tipe 45 bermaterial beton bertulang yang sudah memenuhi standar respon gempa, namun jenis rumah tipe seperti ini tidak memenuhi standar peraturan RTRW untuk pembangunan kawasan pesisir yang rentan pasang dan tsunami, yakni kriteria rumah panggung (Pemerintah Kota Banda Aceh, 2009). Struktur ruang permukiman memanjang dari utara ke selatan dan memiliki tata perumahan terpisah. Perkembangan bangunan umum yang mengikuti sepanjang jalan utama menjadikannya mudah untuk di akses. 


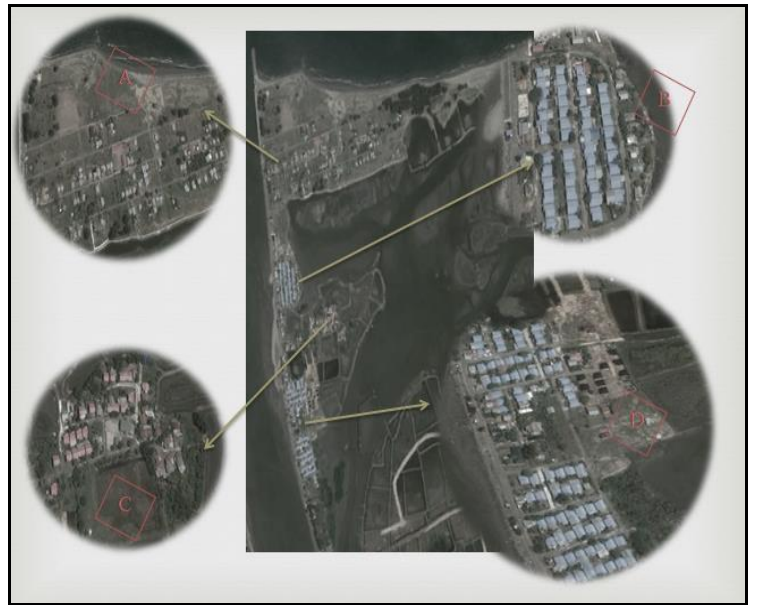

Gambar 3. Pola tata perumahan Alue Naga timur (Analisis, 2021)

Dari gambar dapat diketahui bahwa hanya pola permukiman B yang memenuhi kriteria pola tata ruang yang sesuai dengan kawasan pesisir, yakni pola yang mengikuti garis pantai dengan fasad memanjang dan sisi terbesar bangunan tidak searah arus air sehingga dapat memperkecil bagian yang terkena hempasan gelombang serta memberi ruang untuk arus mengalir bebas untuk memperkecil kerusakan material. Berikut illustrasi perbandingannya;
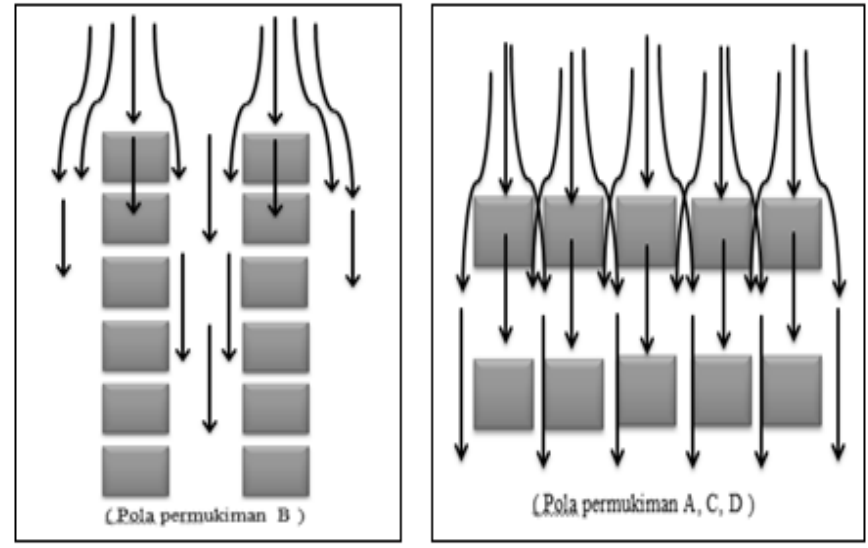

Gambar 4. Illustrasi pola permukiman Alue Naga timur (Analisis, 2021)

Sementara unsur buatan yang berada di dalam kawasan dianggap masih sangat kurang untuk dapat memitigasi tsunami. Dari keseluruhan luasan hanya terdapat 4 unsur buatan.

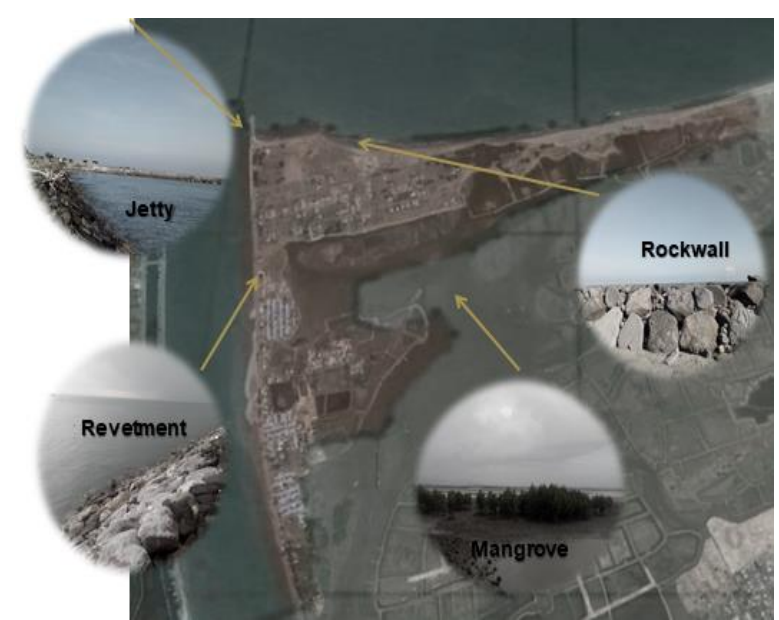

Gambar 5. Unsur buatan di dalam kawasan (Analisi, 2021) 
Keberadaan jetty dan revetment dapat mengurang erosi dan sedimentasi namun tidak dapat mencegah tsunami. Sementara unsur mitigasi rockwall dan mangrove belum memadai. Konstruksi rockwall sering digunakan karena memiliki biaya operasi yang lebih rendah dibandingkan jenis seawall lainnya namun cepat rusak dan tidak tahan lama. Jika terjadi tsunami berintensitas tinggi material debris bebatuan dapat tersapu bersama gelombang ke daratan dan memperparah kerusakan. Sementara mangrove di dalam kawasan hanya sebesar $1,47 \%$ dari luasan seluruh lahan yang di anggap masih sangat kurang dan belum tertata sebagai buffer mitigasi.

b. Variabel jaringan (Network)

Tujuan ke lokasi dikatakan dekat jika berjarak $\leq 2 \mathrm{~km}$ dan dapat ditempuh dalam waktu $\leq 15$ menit. Sementara untuk kawasan Alue Naga jarak tempuh ke zona aman terlampau jauh yakni 1 jam 12 menit dengan jalan kaki. Karenanya kawasan ini membutuhkan gedung evakuasi tsunami.

Rendahnya elevasi Alue Naga yang kurang dari $5 \mathrm{~m}$ menjadikan kawasan tidak memenuhi kriteria pembangunan gedung evakuasi, namun berdasarkan TES-PNPD 2013 terdapat beberapa kriteria pengecualian untuk hal tersebut yang menjadikan Alue Naga layak untuk pembangunan gedung evakuasi dengan beberapa pertimbangan sebagai berikut;

1. Tidak ada bukit alami maupun buatan

2. Tidak ada bangunan dekat pantai

3. Jarak tempuh menuju zona aman terlampau jauh

Jenis tanah alluvial di dalam kawasan juga mempengaruhi proses pembangunan dimana tekstur pasir alluvial berpotensi menyebabkan penurunan muka tanah yang dapat merusak bangunan. Karenannya diperlukan rekayasa untuk mensiasati hal tersebut yakni dengan penimbunan, menambah volume material dengan tujuan meratakan permukaan, meninggikan elevasi, memadatkan struktur tanah untuk mendapatkan permukaan tanah yang lebih baik.

\subsection{Pemahaman Masyarakat akan Mitigasi dan Evakusi (Man) serta Pola Penyebaran Aktivitas di dalam Ruang (Social)}

Analisa terhadap kedua variabel ini menggunakan pengumpulan data dengan cara pembagian kuisioner terhadap 39 sampel yang terdiri dari data responden dan 3 indikator analisis yakni, tindakan sebelum bencana (mitigasi), tindakan saat terjadi bencana (evakuasi) serta penyebaran aktivitas di dalam kawasan (zonasi aktivitas).

Tabel 4. Hasil analisis variabel social (Analisis,2021)

\begin{tabular}{|c|c|}
\hline Menilai & Analisis variabel sosial \\
\hline \multirow{5}{*}{ Mitigasi } & $\begin{array}{l}\text { Persentase masyarakat yang merasa aman tinggal di kawasan Alue Naga timur dari bahaya tsunami } \\
\text { 'sangat rendah'. }\end{array}$ \\
\hline & Tingkat reduksi kawasan terhadap bencana tsunami 'sangat rendah'. \\
\hline & Populasi mangrove belum tertata sebagai buffer sehingga tingkat keefektifitasnya 'rendah/buruk'. \\
\hline & $\begin{array}{l}\text { Keberadaan bank stabilizator dianggap cukup bermanfaat bagi masyarakat sekitar diantaranya } \\
\text { mencegah pengikisan tanah serta sedimentasi yang menghabat kapal nelayan setempat sehingga } \\
\text { dikatagorikan 'cukup' efektif. }\end{array}$ \\
\hline & Efektifitas struktur ruang kawasan dalam mengurangi dampak tsunami dianggap 'sangat rendah'. \\
\hline \multirow{4}{*}{ Evakuasi } & Kawasan memiliki sistem peringatan bencana tsunami berupa sirene. \\
\hline & $\begin{array}{l}\text { Mayoritas masyarakat memperhatikan tanda-tanda alam sebagai sumber informasi memprediksi } \\
\text { bencana tsunami. }\end{array}$ \\
\hline & $\begin{array}{l}\text { Sebanyak } 38,46 \% \text { masyarakat memilih menuju lapangan terbuka saat terjadi gempa dan } 20,51 \% \\
\text { lainnya menjawab bahwa mereka akan langsung mengungsi kedataran tinggi karena trauma akan } \\
\text { tsunami. }\end{array}$ \\
\hline & $\begin{array}{l}\text { Saat terjadi tsunami mayoritas masyarakat menjawab akan mengungsi kedataran tinggi atau menuju } \\
\text { ke tempat sanak keluarga yang aman dari bencana. }\end{array}$ \\
\hline
\end{tabular}


Tabel 5. Hasil analisis variabel man (Analisis, 2021)

\begin{tabular}{|c|c|c|}
\hline \multicolumn{3}{|c|}{ Analisis variabel man } \\
\hline \multirow{2}{*}{ Zonasi pola aktivitas didalam kawasan } \\
\hline waktu & lokasi & $\begin{array}{c}\text { Persentasi } \\
\text { terbanyak }\end{array}$ \\
\hline \multirow{2}{*}{ Pagi } & Rumah & $43,58 \%$ \\
\cline { 2 - 3 }$(00.00-10.00)$ & laut & $30,76 \%$ \\
\hline \multirow{2}{*}{ Siang } & Rumah & $64,10 \%$ \\
\cline { 2 - 3 } & Luar kawasan & $15,38 \%$ \\
\hline \multirow{2}{*}{$(10.00-14.00)$} & Rumah & $74,35 \%$ \\
\cline { 2 - 3 }$(14.00-16.30)$ & Luar kawasan & $12,82 \%$ \\
\hline \multirow{2}{*}{ Petang } & Rumah & $94,87 \%$ \\
\cline { 2 - 3 }$(16.00-18.30)$ & Luar kawasan & $5,12 \%$ \\
\hline Malam & Rumah & $82,05 \%$ \\
\cline { 2 - 3 }$(18.30-00.00)$ & Laut & $17,94 \%$ \\
\hline
\end{tabular}

\subsection{Rekapilitus Hasil Analisis}

\begin{tabular}{|c|c|c|}
\hline No. & Variabel & Kesimpulan hasil analisis \\
\hline 1. & $\begin{array}{l}\text { Nature } \\
\text { (alam) }\end{array}$ & $\begin{array}{l}\text { - Tingkat kerentanan kawasan Alue Naga bagian timur terhadap } \\
\text { tsunami sangat tinggi. }\end{array}$ \\
\hline 2. & $\begin{array}{l}\text { Shell } \\
\text { (permukiman) }\end{array}$ & $\begin{array}{l}\text { - Fisik hunian (rumah) tidak sesuai dengan standar RTRW kawasan } \\
\text { pesisir } \\
\text { - Tatanan pola ruang permukiman shell tidak menggunakan pola yang } \\
\text { sesuai dengan kawasan pesisir. } \\
\text { - Unsur buatan di dalam kawasan belum memadai sebagai mitigasi } \\
\text { tsunami. }\end{array}$ \\
\hline 3. & $\begin{array}{l}\text { Network } \\
\text { (jaringan) }\end{array}$ & $\begin{array}{l}\text { - Kawasan Alue Naga bagian timur tidak memiliki gedung evakuasi dan } \\
\text { hanya mempunyai satu jalur evakuasi utama menuju zona aman } \\
\text { dengan jarak tempuh yang terlampau jauh. }\end{array}$ \\
\hline 4. & Man (Manusia) & $\begin{array}{l}\text { - Pola aktivitas penduduk Alue Naga bagian timur dengan persentase } \\
\text { terbanyak disetiap pembagian waktu berada didalam kawasan. }\end{array}$ \\
\hline 5. & $\begin{array}{c}\text { Social } \\
\text { (masyarakat) }\end{array}$ & $\begin{array}{l}\text { - Pengetahuan masyarakat terhadap mitigasi masih sangat rendah. } \\
\text { - Pengetahuan masyarakat akan evakuasi masih kurang dan masih } \\
\text { banyak penduduk yang trauma akibat tsunami yang melanda } 2004 \\
\text { silam. }\end{array}$ \\
\hline
\end{tabular}

Tabel 6. Rekapilitus analisis semua variabel (Analisa, 2021)

Dari hasil analisis ke 5 variabel dapat disimpulkan bahwa kawasan Alue Naga timur belum siap untuk menghadapi bahaya tsunami. Oleh karenanya perlu dibuat suatu rencana struktur ruang berbasis mitigasi tsunami dengan pendekatan perencanaan yang mempertimbangkan kondisi existing lahan.

Tabel 7. Rekomendasi desain (Analisis, 2021)

\begin{tabular}{|l|l|}
\hline No. & \multicolumn{1}{|c|}{ Rekomendasi Desain } \\
\hline 1. & $\begin{array}{l}\text { Konsep fisik perumahan menggunakan rumah panggung tradisional yang sesuai dengan daerah } \\
\text { rawan gempa tsunami berdasarkan RTRW (akomodatif). }\end{array}$ \\
\hline 2. & $\begin{array}{l}\text { Konsep tatanan ruang permukiman menggunakan pola sejajar garis pantai yang sesuai dengan } \\
\text { kawasan pesisir dengan menempatkan bangunan searah dengan arah datang gelombang sehingga }\end{array}$ \\
\hline
\end{tabular}




\begin{tabular}{|l|l|}
\hline & menimbulkan alur friksi yang rendah terhadap aliran air (akomodatif). \\
\hline 3. & $\begin{array}{l}\text { Penerapan break water/pemecah gelombang sebagai proteksi mengurangi kekuatan gelombang } \\
\text { tsunami serta dapat dimanfaatkan untuk pelabuhan bagi nelayan setempat (protektif). }\end{array}$ \\
\hline 4. & $\begin{array}{l}\text { Konsep penataan vegetasi darat dan vegetasi air (mangrove) sebagai buffer zone untuk } \\
\text { memperlambat energi gelombang. (reetret). }\end{array}$ \\
\hline 5. & Konsep sirkulasi dengan manfaatkan vegetasi sebagai pengarah evakuasi (reetret) \\
\hline 6. & Pembangunan gedung evakuasi sebagai tempat berlindung (protektif) \\
\hline 7. & Mensiasati elevasi tanah dengan penimbunan serta pembuatan artificial hill (protektif) \\
\hline 8. & Melengkapi kawasan dengan peta rawan bencana serta rambu evakuasi \\
\hline 9. & $\begin{array}{l}\text { Memberikan pendidikan atau simulasi tanggap bencana kepada masyarakat melalui acara sosialisasi } \\
\text { sosialisasi (edukasi) serta penambahan kurikulum kebencanaan di sekolah-sekolah. }\end{array}$ \\
\hline
\end{tabular}

\subsection{Konsep Rencana Tata Ruang}

Perencanaan lansekap dijabarkan sebagai pengkajian untuk mengevaluasi secara sistematik area lahan untuk ketetapan penggunaan dimasa yang akan datang (R Hakim, 2003). Konsep perencanaan tata ruang Alue Naga timur dihasilkan berdasarkan proses analisis existing lahan untuk mengetahui permasalahan di dalam kawasan yang kemudian dicocokkan kembali berdasarkan putusan RTRW Banda Aceh, hingga menghasilkan diagram konsep perencanaan ruang sebagai berikut;

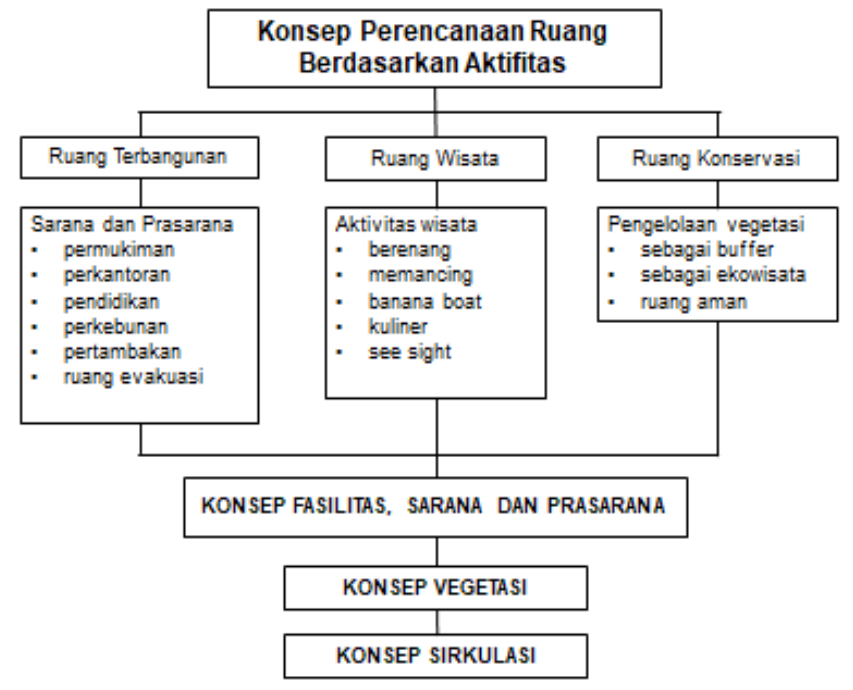

Gambar 6. Diagram perencanaan ruang berdasarkan aktifitas (Analisa, 2021)

Kawasan dibangun dengan fasilitas yang dapat menunjang upaya mitigasi baik melalui konsep tata letak maupun fungsinya. Penataan fasilitas umum mengikuti jalan utama seperti kondisi existing untuk memudahkan akses. Permukiman ditata menggunakan pola yang sejajar dengan garis pantai dan menerapkan konsep rumah panggung yang dapat merespon kelembaban, gelombang maupun gempa.

Konsep sirkulasi memodifikasi sirkulasi yang sudah ada dengan lebar jalan yang mengikuti standar evakuasi. Sirkulasi menggunakan sistem pencapaian frontal yang langsung mengarah ke objek ruang yang dituju sehingga visual objek terlihat dari jauh.

Konsep vegetasi didesain untuk dapat memproteksi ruang terbangun dan ruang wisata. Coastal florest protection merupakan bagian yang akan dibangun bukit buatan sebagai peredam gelombang tsunami yang memanjang secara horizontal disepanjang pesisir pantai. Pada bagian ini akan digunakan tanaman darat yang memiliki sifat peredam gelombang seperti kelapa dan cemara laut. Riverside greenbelt protection berupa mangrove yang dibudidayakan dibeberapa titik tertentu pada bagian sungai untuk mencegah peluapan air sungai saat terjadi tsunami sekaligus mencegah sedimentasi. Sedangkan coastal greenbelt protection dibagi menjadi 2 katagori, yang pertama berfungsi sebagai proteksi ditempatkan dibagian muara pada pintu peralihan masuknya air laut ke daerah rawa dan yang kedua ditempatkan dibagian rawa-rawa yang selain berfungsi sebagai proteksi dan konservasi juga dimanfaatkan sebagai sarana ekowisata edukasi berupa silvofishery dan treeking mangrove. 

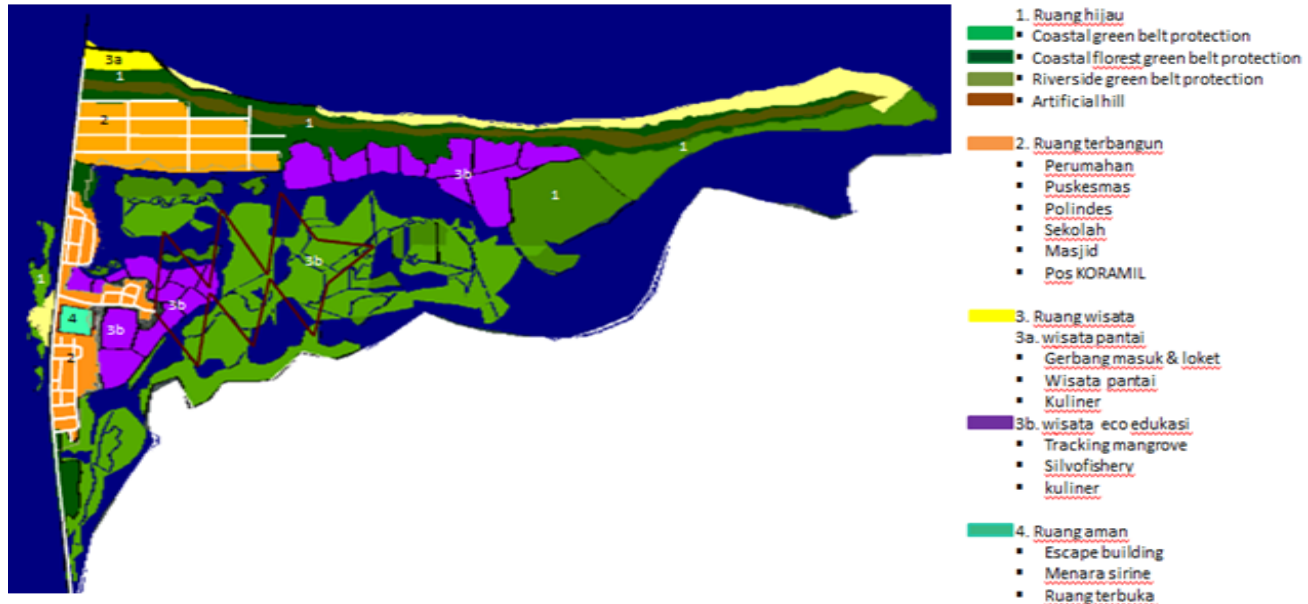

Gambar 7. Rencana blokpan Alue Naga timur (Analisis, 2021)

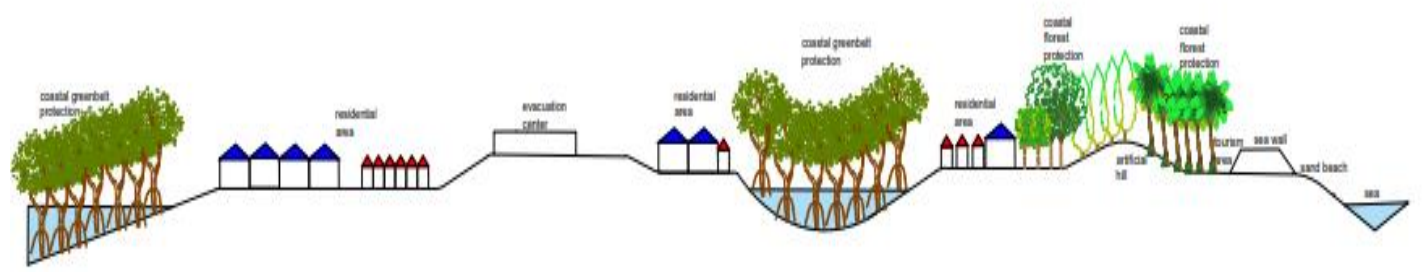

Gambar 8. Illustrasi potongan tata ruang mitigasi Alue Naga timur (Analisa, 2021)

\section{KESIMPULAN}

Alue Naga timur sangat rentan terhadap bahaya tsunami, namun tata ruangnya belum siap untuk menghadapi bencana tersebut. Zona bahaya yang digolongkan kedalam kawasan paling rentan belum siap menghadapi bahaya, sedang masyarakatnya memiliki kesadaran yang rendah akan kebencanaan. Perencanaan struktur ruang berbasis mitigasi bencana tsunami perlu dikembangkan untuk memperkecil dampak kerusakan maupun kerugian. Perencanaan tersebut digembangkan menjadi rencana tata ruang yang terdiri dari konsep sarana \& prasarana, konsep sirkulasi dan konsep vegetasi yang disuguhkan dalam blokplan sebagai hasil akhir analisis. Gempa dan tsunami Aceh 2004 silam seharusnya bisa menjadi pembelajaran penting untuk menyiapkan generasi baru yang siaga bencana.

\section{UCAPAN TERIMAKASIH}

Peneliti mengucapkan terimakasih kepada pembimbing Ibu Dr. Ir Elysa Wulandari, M.T dan copembimbing Ibu Cut Nursaniah, ST, MT serta teman-teman seperjuangan Arsitektur dan Perencanaan Unsyiah yang telah membantu dalam mengumpulkan data maupun informasi untuk tujuan penelitian ini.

\section{DAFTAR PUSTAKA}

Asyiawati, Y., \& Akliyah, L. S. (2011). Identifikasi Dampak Perubahan Fungsi Ekosistem Pesisir Terhadap Lingkungan di Wilayah Pesisir Kecamatan Muaragembong. Jurnal Perencanaan Wilayah Dan Kota, 14(1), 1-13.

BNPB. (2020). Rencana Nasional Penanggulangan Bencana 2020-2024. In Rencana Nasional Penanggulangan Bencana 2020-2024 RINGKASAN. https://www.bnpb.go.id//uploads/renas/1/BUKU RENAS PB.pdf

Direja, A. H. S., \& Wulan, S. (2018). BADAN NASIONAL PENANGGULANGAN BENCANA. Journal Dialog Penanggulangan Bencana BNPB, 9(2), 89-187.

E Wulandari., Fahmi, A., Evalina, Z., \& Myna, A. (2020). The effect of morphology of post-tsunamiA coastal physiography on sustainability system of relocation settlement. Case study: Gampong Saney, Lhoong sub-district, Aceh Besar regency. IOP Conference Series: Earth and Environmental Science, 452(1), 012117. 
https://doi.org/10.1088/1755-1315/452/1/012117

Fairuzahira, S., Rukmi, W., \& Sari, K. (2020). Elemen Pembentuk Permukiman Tradisional Kampung Naga. Tata Kota Dan Daerah, 12(1), 29-38. https://doi.org/10.21776/ub.takoda.2020.012.3

Nursaniah, C., Irwansyah, M., Qadri, L., \& Mariana. (2021). The vulnerability of housing on the north coast of Banda Aceh to disasters from the sea. IOP Conference Series: Materials Science and EngineeringMaterials Science and Engineering, 1087(1), 012031. https://doi.org/10.1088/1757-899x/1087/1/012031

Nursaniah, C., Machdar, I., Munir, A., Irwansyah, M., \& Sawab, H. (2019). Transformation of stilt houses : a way to respond to the environment to be sustainable. IOP Conf. Series: Earth and Environmental Science, 365, 012017. https://doi.org/10.1088/1755-1315/365/1/012017

Pemerintah Kota Banda Aceh. (2009). RENCANA TATA RUANG WILYAH (RTRW) Kota Banda Aceh 2009-2029. Pemerintah Kota Banda Aceh. http://dinaspupr.bandaacehkota.go.id/2018/04/25/rencana-tata-ruang-wilayah-kotabanda-aceh/

R Hakim, H. U. (2003). Komponen Perancangan Arsitektur Lansekap (prinsip-unsur dan aplikasi disain) (1st ed.). Bumi Aksara.

Wulandari, E., Zahriah, \& Fuadi, Z. (2021). Environmental adaptation and hazard reduction strategies in relocation housing development by its occupants case: Indo-Tiongkok housing, Neuheun Aceh Besar. IOP Conference Series: Materials Science and Engineering, 1087(1), 012043. https://doi.org/10.1088/1757-899x/1087/1/012043 